\title{
THE ORIGINS AND TRANSFORMATION OF EARLY IRISH REPUBLICANISM*
}

The history of Irish republicanism has always suffered from an excessive concentration on its later phases. But much light can be thrown on its essential characteristics by a closer examination of its origins. A full understanding of such a contradictory movement would require an investigation of the mutations in public consciousness during the last three centuries. But most historians agree in tracing its origins to the United Irish Society of the 1790's, when the attitudes and conditions which were to dictate the future course of republicanism and loyalism were crystallised. In the light of recent events in Ireland interest in the United Irishmen has revived. ${ }^{1}$ However, even recent research has failed to explain satisfactorily the swift transformation of the United Irishmen's secular republicanism by the traditional fears and aspirations of the Catholic population. Nor has anyone attempted to answer the very basic question of how large sections of a non-political and essentially loyal peasantry could in the short period of the 1790's have acquired many of the fundamental traits of later separatist movements. Already by the turn of the century popular oral culture, latterly dominated by themes taken from Gaelic mythology, speaks instead of dead rebel heroes, of the English oppressor and the Protestant enemy. ${ }^{2}$

* I am grateful to Dr M. R. Beames, Dr D. G. Boyce, Dr Sean Connolly, and M. MacCarthy-Morrogh for their helpful advice ad criticism of various points in this article. 1 P. O'Farrell, Ireland's English Question (London, 1971); Secret Societies in Ireland, ed. by T. D. Williams (Dublin, 1973), especially J. L. McCracken's essay, "The United Irishmen", pp. 58-67; A. T. Q. Stewart, “A Stable and Unseen Power': Dr. William Drennan and the Origins of the United Irishmen", in: Essays Presented to Michael Roberts, ed. by J. Bossy and P. Jupp (Belfast, 1976), pp. 80-92; J. C. Beckett, The Anglo-Irish Tradition (London, 1976), pp. 38-58; P. Gibbon, The Origins of Ulster Unionism (Manchester, 1975); see also his article "The Origins of the Orange Order and the United Irishmen", in: Economy and Society, I (1972), pp. 135-63.

2 See R. K. Alspach, Irish Poetry from the English Invasion to 1798, 2nd ed. (Philadelphia, 1959); Th. Crofton Croker, Researches in the South of Ireland (London, 1824), pp. 328-32; id., Popular Songs Illustrative of the French Invasions (London, 1845), pp. 2-3; E. Wakefield, An Account of Ireland, Statistical and Political (2 vols; London, 1812), II, p. 374; D. J. Case, "Wildgoose Lodge: The Evidence and the Lore", in: Journal of the County Louth Archaeological and Historical Society, XVIII (1974), pp. 152-60. 
This new anti-English flavour in popular culture is particularly significant; English rule in Ireland had not been seriously questioned since the twelfth century, and the failure of the Bruce invasion in the fourteenth century was an indication of general Irish indifference to the nature of central government, provided life's daily routine remained undisturbed. ${ }^{3}$ This attitude characterised Irish thinking for the next four centuries, and like peasant communities elsewhere, the Irish remained essentially apolitical and parochial in outlook. They were scarcely the material from which a movement of national liberation could be fashioned.

In certain conditions, however, modern historians of peasant movements have shown that a traditionally conservative peasant can be attached to a politically revolutionary movement in which he would normally have little interest. Most of the conditions required for such a development were present in Ireland at the end of the eighteenth century: the fierce competition for land caused by a rising population and the development of capitalist farming, and the widespread sense of insecurity which it produced; 4 the existence of a substantial rural industrial workforce in the weavers, capable of acting as transmitters of urban political ideas; ${ }^{5}$ but most important was the sudden development of a serious national crisis and the emergence of a sophisticated revolutionary leadership determined to capitalise on the situation. ${ }^{6}$ In addition, Ireland possessed a number of historical grievances, dormant in normal times, but susceptible to manipulation in times of crisis. These were derived primarily from the existence of a dominant foreign church and ruling class whose power basis was formed on the dispossession and legal subjection of the bulk of the

3 Edward and Robert Bruce carried out a military campaign in Ireland in the period 1315-18, in an attempt to establish a united Celtic Kingdom; see H. F. Hore, "The Bruces in Ireland", in: Ulster Journal of Archaeology, First Series, V (1857), pp. 1-12, and VI (1858), pp. 66-75.

4 See W. H. Crawford, "Landlord-Tenant Relations in Ulster, 1609-1820", in: Irish Economic and Social History, II (1975), pp. 5-21, is particularly informative about the effects of these developments in Armagh and Down. Between 1672 and 1801 the Irish population increased from $1,100,000$ to $5,000,000$, see Hugh Brody, Inishkillane, Change and Decline in the West of Ireland (London, 1973), p. 53.

5 A good account of the pervasiveness of domestic industry in rural areas may be found in J. H. Johnson, "The Two 'Irelands' at the Beginning of the Nineteenth Century", in: Irish Geographical Studies in honour of E. Estyn Evans, ed. by N. Stephens and R. E. Glassock (Belfast, 1970), pp. 224-43.

6 E. J. Hobsbawm, Bandits, 2nd ed. (Harmondsworth, 1972), especially ch. 1; id., "Peasants and Politics", in: Journal of Peasant Studies, I (1973-74), pp. 3-22, and the rejoinder by P. Corrigan, ibid., II (1974-75), pp. 341-5I; E. R. Wolf, "On Peasant Rebellions", in: Peasants and Peasant Societies, ed. by T. Shanin, 4th ed. (Harmondsworth, 1976), pp. 264-74; Rural protest: Peasant Movements and Social Change, ed. by H. A. Landsberger (London, 1974), especially ch. 4, by E. J. Hobsbawm. 
population; and since religion was the excuse used for such subjection, it automatically became the most divisive force within the nation. Traditionally, Irish republicanism has always been urban in inspiration. But in the prevailing conditions of the 1790's it temporarily acquired an appeal to a wider audience in rural and urban Ireland alike.

In the Defender organisation, the primitive industrial society of Ulster had already produced a revolutionary leadership amongst the Catholics before the United Irishmen became republicans. But the Defenders' notion of revolution was based on sectarianism and traditional bitterness at the seventeenth-century confiscations; they played upon the vague peasant notion of their historic right to own the land, and transformed it into a scheme of social revolution to evict and replace the Protestant planter class with Catholics. ${ }^{7}$ Without fully understanding the social aspirations of the Defenders, the United Irish Society arranged an "alliance" between the two organisations and attached to the existing Defender programme its plan to secure Irish independence from England. When the social aims of the Defenders became clear, however, most of the Protestant radicals took fright and scurried to the protection of the Union with England. The religious divisions, which were nearing resolution before 1793 , were given a new emotive force by the events of the 1790's and left to dominate subsequent political movements. It has become unfashionable to reiterate the importance of religious divisions in modern Irish history. ${ }^{8}$ To ignore them, however, is to omit a fundamental element in Irish popular thinking, a source of automatic polarisation on critical issues and an excuse for oppression and victimisation. It was United Irish ignorance of the religious issue which splintered the movement, alienated its best leaders and ultimately exacerbated religious divisions which it had sought to transcend.

This article hopes to show, not that the United Irishmen republicanised Irish society, but that the movement was produced by, and in turn reacted upon, a climate conducive to separatism; that as a result of their activities the debate on the connection with England was for the first time transferred from an intellectual to a popular forum; but that through the numerical superiority of the Catholic Defenders and their greater appeal to particularist Catholic interests, United Irish republicanism was transformed initially into a defensive shield against Orange attacks, but eventually into an equally violent sectarian movement.

7 See below pp. 412-16.

8 See however A. T. Q. Stewart, The Narrow Ground: Aspects of Ulster 1609-1969 (London, 1977), for a re-appraisal of the religious issue. 
As a minority ascendancy group, the Protestants of eighteenth-century Ireland lived in constant dread of a Catholic resurgence. The last Parliament of James II had convinced the Irish Protestants that they could expect little mercy if the Catholic majority ever regained political power. This conviction prevailed for most of the eighteenth century, sustaining the Penal Laws against the Catholics and making the so-called "garrison mentality" of the Protestants a reality in times of crisis. ${ }^{9}$ It was a tragic misreading of Catholic attitudes, which would eventually produce the type of situation that the Protestants believed to exist, and thereby present the republican leaders with a discontented peasantry on which the superficial structure of a national republican movement could be imposed.

However, the eighteenth-century Protestant, and many subsequent commentators, misunderstood the nature of Catholic protest, too often assuming that every disturbance formed part of a general Catholic conspiracy to dispossess the Protestants and destroy the English connection. In normal times the memory of the seventeenth-century conflict did not dictate Catholic actions, and there was little political content in the programme of such agrarian movements as the Whiteboys. It is rather the social function of such groups within the local community which first strikes the observer. In a society where subsistence farming was the norm, with only scattered local industry to provide alternative employment during the winter months, there was an ineluctable attraction for the peasant in the secret society, with its ritual and the community feeling which membership bestowed. ${ }^{10}$ The ritual of "dressing-up" was a notable feature

9 D. H. Smith, "The Volunteer Movement in Ulster; Background and Development, 1745-85" (Ph.D. thesis, Queen's University, Belfast, 1974), pp. 9-10; R. Hobart to E. Nepean, 5 February 1793, Home Office Papers 100/42/246-49, Public Record Office, London; Westmoreland to [Dundas], 24 May 1793, HO 100/43/319-20; see also G. Cornewall Lewis, On Local Disturbances in Ireland (London, 1836), pp. 14-20.

10 For an insight into Irish peasant activities, see M. R. Beames, "Peasant Disturbances, Popular Conspiracies and their control, Ireland, 1798-1852" (Ph.D. thesis Manchester University, 1975); id., "Peasant Movements: Ireland, 1785-1795", in: Journal of Peasant Studies, II, pp. 502-06, and "Concepts and Terms: Cottiers and Conacre in Pre-Famine Ireland”, ibid., pp. 352-53; G. Broeker, Rural Disorder and Police Reform in Ireland, 1812-36 (London, 1970); G. E. Christianson, "Secret Societies and Agrarian Violence in Ireland, 1790-1840", in: Agricultural History, XLVI (1972), pp. 369-84. For the 1790's in particular, see J. G. O. Kerrane, "The Background to the 1798 Rebellion in Co. Meath" (M.A. thesis, University College, Dublin, 1971); T. J. Powell, "The Background to the Wexford Rebellion 1790-1798" (M.A. thesis, University College, Dublin, 1970); Lewis, On Local Disturbances in Ireland, op. cit.; State of the Country Papers 1015-18, State Paper Office, Dublin. But the best account of Irish peasant mentality can still be found in William Carleton, Traits and Stories of the Irish Peasantry (2 vols; Dublin, 1843-44). 
of every such protest group, from the Tories and rapparees of the seventeenth century to the Ribbonmen of the nineteenth. White shirts, ribbons and a motley assortment of other emblems gave a group identity to the participants in nocturnal forays for arms, and the young men of a parish were particularly prominent in such parties. One nineteenth-century commentator wrote on the subject:

It was really a sort of melo-dramatic exhibition. [. . .] There was a frolic, and a spirit of rude enterprise and adventure in meeting, thus attired, with an old gun, or a yeoman's rusty halbert, of a November night, and marching, by moonlight, to the sound of the fiddle or bagpipes, though what end was to be obtained thereby, the great majority of them neither knew nor cared. ${ }^{11}$

Everything reflects the limited and local nature of peasant aspirations; even the nocturnal attacks on landlord holdings fall into the same class of community justice as that outlined by E. P. Thompson in his "Moral Economy of the English Crowd", ${ }^{12}$ with groups of Whiteboys, Peep-O-Day boys, Threshers, Carders etc. seeking to fix a fair rent, prevent an unjust eviction, and regulate tithe payment or the dues levied by the Catholic Church. ${ }^{13}$ Sectarianism was not a pronounced characteristic of these agrarian societies. Rather each was, in Cornewall Lewis's words, "a permanent association, constantly watching over the observance of its rules, and pouncing from time to time on any transgressor of them [...]. It is a protective union, [. . . ] sleeping in apparent apathy so long as its regulations are not violated."14 The resilience of this form of rural "social banditry" was the most enduring characteristic of Irish disturbances in the eighteenth century, and in the 1790's it is frequently difficult to decide whether the disturbances can be attributed to the newer Defender or United Irish organisations or to a resurgence of traditional Whiteboy activity. In this respect the confusion of the authorities at the time only serves to increase the difficulty of distinguishing between the two. ${ }^{15} \mathrm{~A}$ further complicating

${ }^{11}$ W. R. Wilde, Irish Popular Superstitions (Dublin, 1852), p. 81; Carleton, Traits and Stories, op. cit., especially "The Party Fight and Funeral", I, pp. 180-235, and "Wildgoose Lodge", II, pp. 349-62.

${ }_{12}$ E. P. Thompson, "The Moral Economy of the English Crowd in the Eighteenth Century", in: Past \& Present, No 50 (1971), pp. 76-136.

${ }_{13}$ Ribbonism etc., 1798-1839, Colonial Office Papers, Ireland, 904/7, Public Record Office; Aspects of Irish Social History, 1750-1800, ed. by W. H. Crawford and B. Trainor (Belfast, 1969), pp. xi-xii, 33-48; Secret Societies in Ireland, op. cit., especially M. Wall, "The Whiteboys", pp. 13-25, and J. Lee, "The Ribbonmen", pp. 26-35; Beames, "Peasant Disturbances", op. cit.; W. H. Lecky, A History of Ireland in the Eighteenth Century (5 vols; London, 1909), II, pp. 18-44. For an example of such non-political attacks in Tipperary in 1799 and 1800 , see HO 100/87/138-58, 93/194 and 94/227.

14 Lewis, On Local Disturbances, p. 124.

15 Powell, "The Background to the Wexford Rebellion", op. cit., especially pp. 67-84, 194-97. 
factor was the persistence of that peculiarly Irish institution of the faction-fight, where communities, divided by some long-forgotten disagreement, would periodically meet in ritualistic affray, each encounter perpetuating the conflict by providing new reasons for revenge. ${ }^{16}$

After 1793 this blurring of divisions between the more traditional agrarian associations and the new political movements indicates a fundamental characteristic of subsequent Irish conspiracies. Only the leaders appear to have had any clear idea of overall aims; for the rank and file, local considerations continued to predominate. But the general crisis of the period 1795-98, and the terror of a rumoured Orange attack on the Catholics, gave to the localised outbreaks a sense of cohesion and the appearance of a unified national rebellion. Thus, although neither the Defenders nor the United Irishmen succeeded in penetrating the main areas of Whiteboy activity in the South and South-West of the country before 1798, the martial law and "Orange terror" of that year succeeded in attaching even these counties to the revolutionary movement. ${ }^{17}$ The rigid differentiation between "Peasant disturbances" and "Popular conspiracies" as adopted by $M$. R. Beames consequently requires some modification, both geographically and chronologically. Indeed the temporary combination of the existing agrarian societies and a republican leadership as a result of the national crisis, helps to explain the appearance of a widespread revolutionary movement in the twelve months preceding the outbreak of the 1798 rebellion. This is not to claim that one, united revolutionary movement developed during this period; rather a closer examination reveals a conspiracy operating at many different levels. ${ }^{18}$

16 Some examples of such encounters can be found in P. O'Donnel, The Irish Faction Fighters (Dublin, 1975); more informative, however, is Carleton, "The Party Fight and Funeral", loc. cit.

17 The United Irish leaders lamented this failure of their organisation to penetrate the more traditionally disturbed areas, see, e.g., Reinhard to Delacroix, 30 March 1797, Correspondance Politique Angleterre 590, ff. 217-23. Archives des Affaires Etrangères, Paris.

18 The evidence indicating increasing support for revolutionary measures amongst the peasantry in the late 1790 's is overwhelming, though it is clear that few had considered the implications of a French-supported rebellion. See State of the Country Papers 1015-18 for innumerable references to rural support for a French invasion, especially 1015/7, 9A, 32; 1016/7; 1017/10, 12, 37; 1018/3, 15; see also Kent County Record Office, Maidstone, U.840/O.144/8; HO 100/63/205-06, 64/168-72 and 66/50; A Complete Collection of State Trials, ed. by T. B. Howell (33 vols; London, 1809-28), XXV, cc. 754-67. Although peasant disloyalty was a novel development in the 1790's, the events of 1798 ensured its continuation and hopes that France might help overturn English rule remained evident throughout the Napoleonic wars. 
One of the main causes of the crisis in the 1790's was Ulster's exportation of her religious and social problems in the form of the bitterly sectarian Orange and Defender associations. But they would have had less influence elsewhere in Ireland, had their rivalry not touched upon well-established hopes and fears latent in Irish society. These derived principally from the peasantry's tenacious attachment to the land, at times revealing itself in a vague millennialism which envisaged a restoration of the land to Catholic ownership, and lent itself easily to republican manipulation. T. W. Moody, and more recently Aidan Clarke and R. Dudley Edwards, have emphasised that, although the Irish were deprived of the "ownership" of the land by the seventeenth-century confiscations, in many cases they remained in "occupancy". But in those areas where the former landowners were merged with the landless peasantry, the resentments and hopes of the former came in time to dominate peasant thinking. This process was most pronounced in Ulster, and the situation was exacerbated by high rents, short leases and general exploitation of the dispossessed Catholics by the planters. In the rest of Ireland the process of plantation was smoother. ${ }^{19}$ Nevertheless, as $\mathrm{L}$. $M$. Cullen has shown, a sense of resentment against the new landowners was a common feature in those areas where former landowners were reduced to the position of mere tenants. ${ }^{20}$ There is certainly no shortage of contemporary comment on the continued hostility of the dispossessed towards the new owners; the Earl of Westmoreland observed in 1793 that "y lower orders or old Irish consider themselves as plundered and kept out of their property by y English Settlers and on every occasion are ready for Riot and Revenge".21

19 T. W. Moody, "The Treatment of the native population under the scheme for the Plantation of Ulster", in: Irish Historical Studies, I (1938-39), pp. 51-63, and the contributions of Aiden Clarke and R. Dudley Edwards in A New History of Ireland, III: Early Modern Ireland, 1534-1691, ed. by T. W. Moody, F. X. Martin and F. J. Byrne (Oxford, 1976), p. 168-231.

${ }^{20}$ See L. M. Cullen, "The Hidden Ireland: Re-assessment of a Concept", in: Studia Hibernica, No 9 (1969), pp. 7-47; see also W. F. Butler, "Irish Land Tenures: Celtic and Foreign", in: Studies, An Irish Quarterly Review of Letters, Philosophy and Science, XIII (1924), pp. 530-31, and Stewart, The Narrow Ground, op. cit., especially pp. 24-25, 45-46. 21 Westmoreland to [Dundas], 24 May 1793, HO 100/43/319-20; see also H. F. Hore, "The Archaeology of Tenant-Right", in: Ulster Journal of Archaeology, First Series, VI, p. 114; Brody, Inishkillane, op. cit., pp. 48-49; An Enquiry into the Popular discontents in Ireland, by an Irish Country Gentleman (London, 1805), pp. 8-10. J. G. Simms, The Williamite Confiscation in Ireland, 1690-1703 (London, 1956), p. 196, estimates that the percentage of land in Catholic hands declined from 59\% in 1641 to $22 \%$ in 1688 and $14 \%$ in 1703. According to Ruth Dudley Edwards, An Atlas of Irish History (London, 1973), p. 166 , it declined from $90 \%$ in 1603 to $5 \%$ in 1778. 
Such a claim by the eighteenth-century Irish peasant requires some clarification, for under the Gaelic system of land tenure the labourer or "churl" who cultivated the land had no right to ownership. Indeed by the end of the sixteenth century such labourers were in danger of being further downgraded to the position of unfree serfs, as ambitious overlords sought to reinforce their territorial positions by acquiring a permanent supply of a rapidly declining pool of labour. Most of the land was held by clans, septs or extended families; an elected overlord or chief controlled the clan's territory through an ill-defined collection of rules, whilst actually possessing only a portion of the land (his demesne) by hereditary right. Below him society descended through a hierarchical structure from his own relatives, through the collateral septs (cousin branches) and a few nonrelated septs within the lordship, each section possessing its own sub-chief or captain. Relations between the different sections were ill-defined and the Brehon legal system, which purported to regulate such matters, could all too easily be manipulated by the more powerful chiefs, who frequently asserted their rights in such a way as to eventually displace weaker sections. The old Gaelic system was consequently less golden than its eighteenthcentury supporters liked to believe, and although the Brehon Law was not abolished until the reign of James I, its destruction had already commenced internally through the more individualistic attitude of some chiefs. ${ }^{22}$

Outside Munster, where an element of primogeniture already existed in the transfer of clan land, the question of succession rights was a constant source of conflict. The prospect of establishing a more permanent right to clan land played a prominent part in the success of Elizabeth I's policy of "Surrender and Regrant", which converted many elective chieftainships into hereditary lordships. In areas where the policy was applied, the status of the remaining sub-chiefs was depressed to that of mere tenants, thereby creating dispossessed and discontented elements in Irish society before the plantations occurred. In the eighteenth century, however, the many flaws in the Gaelic system were conveniently overlooked. The old Brehon system came to symbolise a golden age to the descendants of the downgraded septs, and as late as 1812 its loss was still lamented in popular songs such as the Lament of $O$ 'Gnive:

Afflictions dark waters your spirits have bow'd And oppression hath wrapped all your land in a shroud,

Since first from the Brehons pure justice you stray'd,

And bent to those laws the proud Saxon has made. ${ }^{23}$

${ }^{22}$ See Nicholas Canny, "Hugh O'Neill and the charging face of Gaelic Ulster", in: Studia Hibernica, No 10 (1970), pp. 7-35.

23 "The Lament of O'Gnive", quoted in Croker, Popular Songs, op. cit., p. 23. 
Naturally in such a society lineage was of utmost importance. Even after dispossession had occurred, ancestral claims were carefully preserved by a steadily increasing number of descendants, as successive generations of the extended family multiplied themselves. Arthur Young observed in 1776 that

Families were so numerous and so united in clans, that the heir of the estate was always known; and it is a fact that in most parts of the kingdom the descendants of the old landowners regularly transmit by testamentary deed the memorial of their right to these estates which once belonged to their families. ${ }^{24}$

It is important, therefore, to distinguish between personal claims to land and a collective if vaguer claim to the ancestral family lands, which dominates such eighteenth-century laments for the past. It is true that after the more general removal of the native upper class in the Cromwellian and Stuart plantations of the seventeenth century, the bardic laments reflect "aristocratic" rather than popular sentiments, and most of the disaffected of the late eighteenth who glibly reiterated Defender phrases about their natural right to the land would have found little historic justification for such claims. Nevertheless it would be foolish to dismiss the strong sense of kinship in Irish society which gave the grievance of the dispossessed of the sixteenth and seventeenth centuries a more general applicability. Certainly the diffusion of United Irish and Defender propaganda in the 1790's would be an insufficient explanation for the prevalence of the hope that French assistance would secure a restoration of ancestral lands to the rightful claimants. ${ }^{25}$

The initial plantation policy for Ulster had differed considerably from that adopted in the country as a whole. In the six escheated counties the Irish were to have been completely replaced by imported English and Scottish settlers, and segregated in selected areas. Although the policy was never fully implemented, about 13,000 settlers had been introduced, and tolerance of continued Irish occupancy was accompanied by increasingly severe measures against the Catholics. Official policy had consequently

${ }^{24}$ A. Young, A Tour in Ireland, ed. by Constantia Maxwell (Cambridge, 1925), pp. 193-94.

${ }^{25}$ K. Nicholls, Gaelic and Gaelicised Ireland in the Middle Ages (Dublin, 1972); see also Hore, "The Archaeology of Tenant-Right", loc. cit.; R. D. Crotty, Irish Agricultural Production, Its Volume and Structure (Cork, 1966), pp. 1-32. For a more detailed account of the workings of the Brehon Laws, see G. Hand, English Law in Ireland 1290-1324 (Cambridge, 1967), especially pp. 188 and 192-95; G. Sigerson, History of the Land Tenures and Land Classes of Ireland (London, 1871), ch. 1; W. F. Butler, "The Brehon Land System", in: Studies, op. cit., XIII, pp. 291-305 and 524-40; Wakefield, An Account of Ireland, op. cit., I, p. 238. 
rendered the struggle for the land and religious friction inextricable. ${ }^{26}$ The "inferior classes" in Ulster were thereby divided within themselves, and a separate class identity never permitted to develop. The result was an unnatural alliance between upper and lower levels of Protestant society, which in the 1790's was to endow sectarian attacks on Catholics with the appearance of landlord and ultimately government support. This was to play a crucial role in the alienation of the Catholic peasantry after the "Armagh Outrages" of 1795-96.

A second consequence of the Ulster plantation was a greater level of political awareness among the peasantry than elsewhere in Ireland. For most of the eighteenth century the economic ascendancy of the Protestant tenant was an established fact. But the progressive relaxation of the Penal Code towards the end of the century, notably the grant of the franchise to the Catholics in 1793, rendered the Catholics as attractive a proposition to the landlord as his Protestant counterpart. By the 1790's, therefore, the Protestant weaver or small tenant was faced with increasing competition for land from a Catholic population which was growing rapidly, threatening the numerical in addition to the economic superiority of the Ulster Protestant. ${ }^{27}$ As a result, the conflict between the two religious groupings had become open, continuous and inevitably sectarian. In most of the Ulster counties the Protestant monopoly of the means of suppression, a ready supply of arms and the frequent collusion of the local landlords and magistrates meant ultimate victory over the Catholics. Many Catholics were forced to flee or continue their protest in secret and increasingly subversive societies. The local magistrates remarked upon the political awareness of the Ulster Catholics fleeing to the South, and as the government had feared, the refugees were to prove remarkably successful in spreading that type of seditious organisation with sectarian undertones which had prevailed in Ulster. ${ }^{28}$

26 Clarke and Edwards, loc. cit., pp. 196-237.

${ }^{27}$ See table, also J. N. Brown, "Nationalism and the Irish Peasant, 1800-1848", in: The Review of Politics, XV (1953), p. 403.

28 See Camden's letters to Portland, 26 May 1795, Rebellion Papers 620/22/8, State Paper Office, and 6 August 1795, HO 100/64/168-72; H. Senior, Orangeism in Ireland and Britain (London, 1966), pp. 46-47; P. Tohall, "The Diamond Fight of 1795 and the Resultant Expulsions”, in: Seanchas Ardmacha, III (1958), pp. 17-50. The United Irish leaders themselves attributed the rapid spread of their society in 1796-97 to the effects of the "Armagh Outrages", see W. J. MacNeven, Pieces of Irish History (New York, 1807), pp. 186-87. 
Table illustrating the proportion of Catholics to Protestants, $1732-1834^{29}$

1732

1766

1834

Ulster

Catholic

192,295

268,323

$1,955,123$

Protestant

313,120

353,740

$1,171,618$

Munster

Catholic

532,035

612,944

$2,220,346$

Protestant

66,685

102,714

115,233

Leinster

Catholic

462,170

534,769

$1,063,681$

Protestant

126,205

147,806

183,609

Connacht

Catholic

220,505

289,423

$1,188,568$

Protestant

21,495

32,441

45,768

Total

Catholic

$1,407,005$

$1,705,459$

$6,427,712$

Protestant

527,505

636,701

$1,516,228$

III

But the Defender and United Irish movements might have remained Ulster phenomena, had not a national crisis occurred to make the plight of the Ulster Catholics the concern of their co-religionists elsewhere. ${ }^{30}$ In such a crisis, which directly affected the traditional way of life of the peasant, and where certain members of the community were capable of assimilating

29 The population statistics for 1732 are taken from An Abstract of the Numbers of Protestant and Popish Families in the Several Counties and Provinces of Ireland Taken from the Returns made by the Hearthmoney office in Dublin, 1732-33 (Dublin, 1734); those for 1766 from Wakefield, An Account of Ireland, II, p. 587; and those for 1834 from the First Report of the Commission on Public Instruction, Ireland (London, 1835), pp. 9-35, J. R. McCulloch, A Statistical Account of the British Empire, 2nd ed. (2 vols; London, 1839), II, p. 311, and G. De Beaumont, L'Irlande Sociale, Politique et Religieuse ( 2 vols; Pars, 1839), II, p. 390. Estimates of Ireland's population in the eighteenth century are notoriously defective; for example, K. H. Connell, The Population of Ireland, 1750-1845 (Oxford, 1950), p. 12, increases many estimates, notably the oft-quoted figures of D. A. Beaufort in 1792, by as much as a million. Most estimates were calculated by multiplying hearth-tax returns by a notional figure of five persons per household.

30 Wakefield, An Account of Ireland, II, pp. 359-62, outlines the manner in which the latent fears in Irish society became exaggerated during this period. 
and transmitting revolutionary ideas, the conservative Irish peasantry temporarily acquired many of the characteristics of a revolutionary movement. But unless traditional peasant aims are understood and harnessed by the revolutionary leadership, they can come to dominate and ultimately destroy the movement. The remainder of the article will concentrate on the development of a crisis and potentially revolutionary situation in the 1790's. The revolutionary leaders capitalised on the situation and temporarily attached the peasants to their movement to give it a superficially national character. However, they failed to control the peasant passions which they had encouraged but which eventually engulfed their own movement.

In the last quarter of the eighteenth century the long quiescence of the Catholic population had fostered a more liberal attitude among sections of the Protestant population. The Irish parliamentary opposition began to appeal to the country to support its programme of reducing England's stranglehold over the country's economic and political life and of relaxing the penal laws against the Catholics. Like the United Irishmen, they tended to translate reform ideas into images readily comprehensible to the Irish peasant, arousing greater expectations among the Catholics than they could or wished to satisfy. In this period the country was kept in a state of political fermentation and Volunteer parades, non-importation societies, preparations for a national convention, and constant harangues from reformers inside and outside Parliament maintained Catholic hopes for an improvement in their situation. This exposure of large sections of the unenfranchised populace to ideas of reform and emancipation created a ready audience for French revolutionary ideals, re-interpreted by the Defenders and the United Irishmen to suit Irish grudges and grievances.

It was the Defenders rather than the United Irishmen who were initially responsible for thus correlating French ideals with traditional Catholic aspirations. Defenderism originated in Ulster in the mid 1780's as a response to Protestant agrarian attacks. But at the outset it was neither purely lower-class nor Catholic in composition. ${ }^{31}$ That it became so in the course of its expansion outside Ulster was primarily the result of warinduced fears on the part of the Protestant authorities. ${ }^{32}$ In 1790 , the Dublin-based Catholic Committee, which had been agitating for Catholic relief since the 1760's, had experienced a major change in leadership and tactics. The new leaders then embarked on a national campaign for Catholic emancipation, despatched delegates into the provinces and made

31 Aspects of Irish Social History, op. cit., pp. 171-76.

32 The war between England and revolutionary France commenced in February 1793. 
arrangements for elections to an extra-parliamentary convention. In the course of this campaign, the Catholic delegates naturally came into contact with the Defenders. There is no evidence to associate the middle-class Catholic Committee with the more extreme aims of the Defenders; but given the traditional Protestant fears of a Catholic resurgence, the association in government minds is understandable. Such an attitude of "guilty before proven innocent" simply confirmed the growing Catholic realisation in the 1790's that no further concessions could be expected from the Irish authorities. Indeed John Keogh, one of the leading members of the Catholic Committee, claimed that the panic reaction of the authorities to the peaceful Catholic reform campaign was actually destroying Catholic loyalty. ${ }^{33}$ Other less biased observers foresaw the consequences of failing to concede the reasonable demands of the Catholics. Richard Burke warned that "the Catholics are averse to republican principles and nothing could drive them that way but rage and despair at the conduct of government". ${ }^{34}$ The bitter reprisals taken by the Irish government against the Defenders, the war-time emergency measures curtailing popular reform movements, and the dramatic rejection of Catholic emancipation during the Fitzwilliam episode of 1795 gradually turned the Catholics more and more towards a republican resolution of their plight. ${ }^{35}$

The aims of the Defenders were extremely diverse, normally reflecting the grievances of the different localities into which the movement penetrated; the reduction of tithes, hearth-money and rents, and some change in the system of land-holding were, however, general aims in every district. But unlike the programmes of previous agrarian societies, that of the Defenders also included vague plans to assist a French invasion, bring about an Irish rebellion and secure a redistribution of Protestant estates among the Catholics. Much of the developing sectarianism in Defenderism was a response to the increasingly discriminatory policy of the frightened Protestant authorities towards the Catholics; ${ }^{36}$ whilst signs of agitation in

${ }^{33}$ Kerrane, "The Background of the 1798 Rebellion in Co. Meath", op. cit., ch. II; Report from the Secret Committee of the House of Lords, March 1793, HO 100/43/91-94; A Complete Collection of State Trials, op. cit., XXV, cc. 749-84.

${ }^{34}$ Burke to unknown, 10 November 1792, HO 100/34/224; see also Col. Doyle to the Prince of Wales, 15 February 1792, National Library of Ireland, Dublin, Ms. 54A/76.

${ }^{35}$ The Diary of Thomas Russell for 1793, Rebellion Papers 620/21/23; Extracts of various letters of information relating to the late Insurrection, May-June 1793, HO 100/44/115-18; Reports of Disturbances in Ireland, March-August 1975, Kent County Record Office, U.840/O.144/9.

${ }^{36}$ Kerrane, "The Background to the 1798 Rebellion", p. 6. Kerrane sees official repression as the main cause of increasing popular support for republicanism. See also Westmoreland to Dundas, 25 May 1793, HO 100/43/321-28, and Dr McDonnel to R. R. Madden, 1842, Trinity College, Dublin, Ms. 873/381. 
the Catholic community were frequently simply another aspect of the general social turmoil caused by the early stages of the war with France. ${ }^{37}$ But Defender promises of French assistance to secure a transfer of land and political power from the Protestants to the Catholics revived old prejudices, and by 1793 support for France had already become inseparable in Catholic minds from the idea of a new millennium in which they would again own the land. Irish hopes of a general transfer of land on a French landing would have remained unrequited, for France envisaged little alteration in Ireland's social and political structure after independence. Rather she hoped to secure the support of the Protestants, fearing that the Catholics might prove too attached to their religion to give genuine support to the areligious if not irreligious French Republic. ${ }^{38}$

The Irish government was baffled by signs of growing political awareness amongst the Defenders in the winter months of 1792-93. But it continued to dismiss the movement as politically unsophisticated, incapable of generating the revolutionary ideals which had begun to appear in their declarations. Rather it sought to explain the dissemination of French ideas in terms of outside influences, from middle-class intellectuals in the Catholic Committee or the United Irish Society. ${ }^{39}$ Such inferences were hotly disputed by both groups, and all the signs are that the Defenders had already assimilated French ideas of revolution unaided by any outside force apart from the general publicity given to events in France and the writings of Tom Paine. But one aspect of the garbled revolutionary ideas spread by the Defenders was entirely home-grown and caused the authorities particular anxiety. This was the peculiarly Catholic interpretation placed upon such theories by the Defender leaders, who assured their followers "that within the space of a week [March 1793] they expected assistance from France; and [...] they would get the conditions of Limerick; $;^{40}$ that the Protestants had the power of the country long enough, and that they [the Catholics] would have it as long more." 41 In a society

37 Dublin Evening Post, 15 November 1792; Hobart to Nepean, 8 June 1793, HO 100/34/134; Mrs McTier to Dr W. Drennan, 3 August 1794, Public Record Office Northern Ireland, Belfast, T 765/520; Hobart to Nepean, 19 October 1792, Private Official Correspondence VIII A/1/3/239, State Paper Office.

${ }^{38}$ [Benoist] to Lebrun, 1 December 1792, and Memoir on Ireland, December 1792, Correspondance Politique Angleterre 584, ff. 9-11, 408-11; also report by Col. Oswald on his mission to Ireland, 11 June 1793, ibid., 587, ff. 167-68.

39 Westmoreland to Dundas, 29 March 1793, HO 100/43/145-51.

40 The Treaty of Limerick was concluded between the Irish Jacobite forces and the supporters of William of Orange in 1691. It guaranteed toleration to the Catholics, but its terms were not honoured by the Protestant victors.

41 State Trials, XXV, c. 754. 
which was barely literate, orally transmitted French ideals inevitably reached the peasants in a form rephrased to suit local conditions. The most common interpretation derived from the traditional socio-religious bitterness within Irish society; many Catholics saw Defender plans of revolution primarily as a "scheme to knock the Protestants on the head, and [...] take their places" or a tool "to destroy the Protestant religion, and pay no tithes or taxes". 42

In the early stages of the war the Defenders had succeeded in convincing the Catholics that France genuinely wished to help them. But it is unlikely that the Irish peasantry ever understood the significance of events in revolutionary France, and the reaction of the Connacht peasants to the French landing in 1798, which so shocked the French officers, was probably an accurate reflection of general Catholic attitudes towards the Republic.

Presque tous ces demi-sauvages sont catholiques et d'un fanatisme rebutant qui fait vraiment pitié. [...] ils se précipitaient au devant de nous, se prosternaient à nos pieds et la tête dans la boue récitaient de longues prières pour nos succès; tous, hommes et femmes, portent pendus à leurs cous de larges, sales et crasseux scapulaires ainsi que des chapelets ou rosaires. [...] notre gouvernement a été trompé sur la situation de ce pays. ${ }^{43}$

This primitive response to the invading French soldiers is indicative of the manner in which the Catholics still looked to France as a traditional ally, their protector of the seventeenth century, who would fight again for a Catholic settlement. They scarcely realised that a revolution had taken place in France.

la plupart ignoraient même jusqu'au nom des français [...]. Ces malheureux insulaires n'en portoient pas moins l'enthousiasme de la Liberté; [...] ils nous regardaient comme leurs libérateurs et les protecteurs nés de leur religion qui est Catholique. ${ }^{44}$

The memory of the past was sufficiently strong to explain Catholic enthusiasm at French successes in the continental war, and although the Lord Lieutenant, Lord Camden, was sceptical of French willingness to help the Irish, he realised the potency of such an expectation in sustaining Catholic agitation.

Your Grace and His Majesty's Ministers can alone judge of the probability of the French being able to give that active and actual assistance which I

42 Ibid., cc. 757, 761.

43 J. L. Jobit, Journal de l'Expédition d'Irlande (1798), Archives Historiques de la Guerre, Paris, MR 506.

44 J. B. Thomas, Souvenirs de ma vie militaire (undated), pp. 55-56, ibid., B ${ }^{112}$. 
have no doubt the disaffected in this county have sollicited [sic] and expect. - It is however that expectation which gives energy and vigor to their exertions, and the possibility of which leads me to consider this subject with more apprehension than I should otherwise think it deserved. ${ }^{45}$

There is little evidence to support Protestant fears of French influence behind the disturbances of 1792-93. Before the declaration of war in 1793, France valued the Irish troubles primarily as a means of diverting English attention from affairs on the continent, and she ostentatiously avoided involvement in Irish affairs. ${ }^{46}$ Even after the outbreak of war, French missions to Ireland were characterised by a casualness which scarcely supports the fears of the Dublin government. ${ }^{47}$

The first attempt to enlist French aid for a rebellion had actually come from the Irish themselves, and evidence suggests that the Defenders were the main participants in negotiations. Throughout the latter months of 1792 Defender raids for arms escalated; large quantities of ammunition were reported to have arrived from England, a rising was said to be imminent, and the leaders held out promises of French assistance as a further inducement to militancy. In the autumn of that year a party of lish revolutionaries had made overtures to a French official in London. The ensuing negotiations are surrounded in obscurity. We know neither the names of the representatives nor those of the "Revolutionary Committee" which they claimed to represent. The first meeting may well have been a chance encounter, since French agents in London at this period were permitted a remarkable amount of freedom to mingle in radical company. But as a result of this meeting the agent was instructed by the home government to open negotiations with the Irish revolutionaries. They told him of a four-man "Revolutionary Committee" in Ireland, which had been formed to make preparations for a winter rising. Their account of these preparations, and subsequent claims made by their agent in Paris, indicate that some of the members of the London delegation were Defenders. The 1792 representatives exaggerated the support for independence in Ireland to combat French scepticism, in much the same way as United Irish agents

45 HO $100 / 64 / 168-72$.

46 Correspondance Politique Angleterre 582, especially ff. 38-44, 219-28, and 583, ff. 40-52, 174; also Lebrun to Grenville, 1 February 1793, Foreign Office Papers 27/41, Public Record Office.

47 In 1793 two French missions were despatched to Ireland, one led by William Duckett, the other by Col. Eleazer Oswald, see Correspondance Politique Angleterre 586, ff. 391-92, and 587, ff. 167-68, for their reports; also memoir by Duckett, 1 November 1793, Archives Historiques de la Guerre, $\mathrm{B}^{112}$. 
in Paris after 1796. Their success in convincing the French agent of overwhelming Irish antipathy towards England prompted him to give more enthusiastic promises of French aid than authorised by his original instructions. The assurances of French support with which the Defender leaders encouraged their followers were consequently not as groundless as the English and Irish governments would have liked to believe. These early overtures had no sequel due to the timely action taken in Ireland against the Defenders and the political confusion in France. ${ }^{48}$ It is therefore difficult to assess the exact nature of preparations for a revolution in the winter of 1792-93. But the Irish authorities do speak of the riots which engulfed Ireland in the spring of 1793 as an "insurrection", and the actions of the rioters reveal a new note of militancy, supported by a greater show of arms than any earlier outbreak of agrarian disturbances. ${ }^{49}$

This insight afforded into the Defender organisation by the French negotiations indicates a more sophisticated movement than the traditional historical picture would have us believe. They were certainly not the "ineffective group of rebellious peasants" dismissed in a few words by Strauss. The Defenders had already postulated ideas of a national revolution before their association with the United Irishmen began in 1795, even though such ideas were interpreted in a traditionally Catholic manner. ${ }^{50} \mathrm{~J}$. G. O. Kerrane, repeating a claim made by Camden, speaks of a "merger" having taken place between the Defenders and the United Irishmen in the years $1795-96 .{ }^{51}$ The term is misleading, for the ultimate aims of the two movements were mutually antagonistic. The United Irish Society imposed its more efficient hierarchical structure on the Defenders and temporarily harnessed their numerical superiority to its programme of secular republicanism, in which social and religious, but not necessarily political and economic equality predominated. But the rank-and-file Defenders did not want equality; rather they sought the political and economic superiority to which they felt their numbers and historic claims entitled them. Early republicanism was consequently bitterly divided along lines which permitted of no easy solution, and only became less so as

48 For accounts of increased arming in Ireland, see HO 42/22/153, 181, 316, 318; $42 / 23 / 214 ; 100 / 42 / 69-70$. For the negotiations with France, see correspondence between Lebrun and [Benoist], December 1793, Correspondance Politique Angleterre 584, ff. 9-11, 98-99; correspondence with and concerning Ferris, the Irish agent, July-August 1793, ibid., 586, ff. 296-300, 306-07.

49 HO $100 / 43 / 1-4,43 / 321$ and 331 , and $44 / 5$ for official correspondence on the "insurrection" of the winter and spring of 1793 .

50 E. Strauss, Irish Nationalism and British Democracy (London, 1951), p. 51.

51 Kerrane, "The Background to the 1798 Rebellion", pp. 70-76. 
the United Irish brand of republicanism was pushed out by the wider appeal of the traditional Catholic interpretation. Given the existing historic conflict, the United Irishmen's philosophy could have done little more than ice the surface.

A closer association between the United Irishmen and the Defenders was inevitable; but there is little evidence that the United Irish leadership, even its Catholic members, sympathised with the wider aspirations of the Defenders. Indeed many, including Tone himself, envisaged an Irish republic in which the Catholics would continue to play an inferior role. The feeling that the Catholics would be incapable of administering a republican state was carried to France by the United Irish emissaries and confirmed French opinion that a complete regeneration of Irish society would be required before a republican government could be established. ${ }^{52}$ United Irish proselytisation among the Defenders was to remain a piecemeal policy of the younger militant leaders in Dublin and Belfast, the remaining leaders, even the Catholics retreating in horror at the social revolution they had unleashed.

\section{IV}

The declaration of war between France and England in 1793 transformed France's passive interest in Ireland into one of active missionising. In May 1793 offers of French assistance were rejected by the United Irishmen, who felt that Ireland was not yet ready for a rising. ${ }^{53}$ But when William Jackson arrived in April 1794 with a similar offer, he found the United Irish Society already divided on the issues of French help and Irish revolution. Many leaders refused to meet Jackson, but a handful, including some former members of the Catholic Committee, welcomed his suggestions. ${ }^{54}$ Jackson was later arrested, and the thwarted "plot" was given full publicity by the

52 R. Jacob, The Rise of the United Irishmen (London, 1937), p. 19; Notes on sources of the Sheares Papers, Trinity College, Ms. 873/456; Information from S. Turner, 7 February 1801, Foreign Office Papers 33/21/13. See also various statements by W. J. MacNeven in copy of Minutes of a conversation between Mr. Marsden and Dr. McNevin [sic], 29 October 1798, Public Record Office, PRO 30/8/325/1/15-16; Mémoire sur l'Irlande et sur les Irlandais-Unis [. . . par M. Poterat, 8 January 1803, Correspondance Politique Angleterre 601, ff, 43-46; MacNeven, Pieces of Irish History, op. cit., pp. 197, 206, 223.

53 Correspondence concerning the mission of Col. Oswald, Correspondance Politique Angleterre 587, ff. 167-68, 170, 176; 588, ff. 267-70.

54 Information sent to E. Cooke, February-August 1793, Rebellion Papers 620/20/72 and 21/27-38; The Life of T. W. Tone, ed. by his son, William T. W. Tone ( 2 vols; Washington, 1825), I, pp. 112, 120; Memoir of A. H. Rowan, 2 October 1794, Correspondance Politique Angleterre 588, ff. 262-64. 
Irish government, in the naive belief that such action would frighten away moderate support for the United Irish Society.

But the authorities had seriously miscalculated in the timing and publicity given to Jackson's trial in 1795. Defenderism had been in decline since the beginning of $1794_{2}$ and the country was calmer than it had been for many years. ${ }^{55}$ Initially Jackson's mission and arrest had aroused little public interest. But towards the end of 1794 the question of Catholic emancipation again became a burning issue because of the rumoured appointment of a pro-Catholic Whig Lord Lieutenant. When Fitzwilliam, the new Lord Lieutenant, arrived the following January, he found the country already in fermentation over the Catholic issue and soon became convinced of the urgency of immediately granting Catholic emancipation. ${ }^{56}$ Amidst rising public hopes that the issue was as good as settled, Fitzwilliam was abruptly recalled to England after a sharp reprimand by Pitt. The result was an immediate outburst of riots in the capital, and the hostile reception of the new Lord Lieutenant was an indication that the uneasy truce between the populace and the administration was ended. The United Irish remnant dropped all pretence at moderation and officially adopted a policy of "alliance" with the Defenders. Defenderism was revived in a more political form, and by the following winter many counties were reported to be "infested" by the system. ${ }^{57}$ Much of the disturbance was the product of traditional Whiteboy activity. But in the crisis situation, the Dublin government read political motives into every local affray, and the stringent Insurrection Act, passed in 1796 as a result of official fears, did much to temporarily attach old Whiteboyism to the newer political movement.

The revolutionary element in Irish society, which developed from 1795 onwards, was not primarily a French creation. Rather, increasing signs of reaction in Irish government circles, following a long period when hopes of Catholic reform had been encouraged, created a climate of opinion in which the acceptance of French assistance seemed the only natural course to take. Until 1795 discontent in the country had been unco-ordinated and poorly led. Thereafter a marked tone of disloyalty spread through the nation, and the association of a French invasion with internal insurrection became the standard theme of Defender oaths. ${ }^{58}$ The small group of 55 Kerrane, "The Background to the 1798 Rebellion", pp. 50-53, and Lecky, Ireland in the Eighteenth Century, III, pp. 225, 231.

56 Letters of Fitzwilliam to Portland, January-February 1795, HO 100/46/259-76.

57 Camden to Portland, 5 March 1796, HO 100/63/215-21.

58 State Trials, XXVI, cc. 437-62; Dr W. Drennan to Mrs McTier, 31 August 1795, Public Record Office Northern Ireland, T 765/579; Copy of a Paper-writing found [...] at Cavan 21 June 1795, HO 100/58/201-03; T. Pelham to J. King, 1 March 1796, HO 100/63/205-06. 
United Irish leaders which had greeted Jackson's suggestions with enthusiasm, was left to take the movement into its second, its republican phase. This phase saw the beginnings of organised republicanism in Ireland, but its character was to be dictated by forces outside the Society's immediate control. If the negotiations with France had transformed the Society into a treasonable organisation, the conflict between the Irish Protestants and Catholics was soon to alter its nature and ideals. This conflict was revived in a particularly violent manner in the first year of the republican movement's existence, and not surprisingly it was in Ulster that the sectarian brands of republicanism and loyalism had their origins.

Clashes between the dissenters and Defenders of County Armagh had been growing in intensity since 1791, and by 1795 the Defenders had already spread that terror of attack by the Protestants which was to play a major role in pushing the Catholics towards rebellion in 1798. The attacks upon the Catholics had become institutionalised after the formation of the Orange Order in 1795, and the persecution reached such a pitch in the following summer and winter, that thousands of Catholics were forced to flee to other counties. ${ }^{59}$ These "Armagh Outrages", occurring in an atmosphere of deepening reaction on the part of the authorities, were one of the most important turning points in the development of early Irish republicanism. The Catholic refugees from Ulster were more effective agents of revolution than the intellectual United Irish leaders could ever have been, and the influx of new recruits into the Defender and United Irish organisations after $\mathbf{1 7 9 5}$ owed much to the terror of Orange attack, which the refugees had exported from Ulster. The Dublin government was fully aware of the possible repercussions of the Orange attacks, but in its panic at the thought of external attack from France and internal rebellion, it seemed incapable of halting the spiral reaction which followed the "Armagh Outrages". In August 1796 Camden described the dilemma in one of his many fraught letters on the subject to the Duke of Portland, the Home Secretary:

Your Grace has been long informed of the unfortunate feud which for several years had prevailed in the county of Armagh between the Dissenters and the Roman Catholics of the inferior classes. The former, in the course of last summer having after some petty conflicts gained an ascendancy in that County over the Catholics, increased every revengeful process in their Power, [. . . ] a great multitude of Families fled the County, and were obliged to resort for new Settlements to other parts of the Kingdom, where they

59 Estimates of the number of Catholics to take refuge in other counties range from 180 to 700 families (approx. 900-3,500 individuals). See Kent County Record Office, U.840/ O.151/4 and 173/1; also Senior, Orangeism in Ireland and Britain, op. cit., p. 30. 
related their Sufferings and I fear have excited a spirit of Revenge among their Catholic Brethren. The United Irishmen of Belfast [...] took advantage of this ill conduct of the Dissenters in Armagh to form a junction with the Societies of Defenders in the Western and midland counties, and to revive their Committees and assemblies [...]. Recently, Emissaries have been among them to influence them against the Dissenters of Armagh, to instill into their minds that the persecution of the Catholics is protected by Government to excite them to join the United Irishmen, and to fill them with hopes of a French Invasion, ${ }^{60}$

Camden regarded the Orangemen as potentially more dangerous than the revolutionary societies: "they give a pretence for the disaffected to act upon." ${ }^{11}$ But the deteriorating situation in the country and increasing signs of anti-Protestant activity amongst the peasantry created a similar terror among the Protestant authorities, and they began to exert mounting pressure on the Lord Lieutenant to entrust them with greater powers to suppress the troubles. In view of Defender success in recruiting members of the predominantly Catholic militia, and his realisation that ultimately the government was dependent on the Protestant landowners to preserve law and order, Camden submitted to the pressure. In the course of 1796 he gave the Protestant gentry almost total power to suppress the disturbances, by means of the stringent Insurrection Act of February, the suspension of Habeas Corpus in October and an almost exclusively Protestant yeomanry force which they would be responsible for raising. Since a number of the gentry were Orange sympathisers, Camden's action seemed to justify United Irish claims that the attacks on the Catholics were sanctioned by the government. ${ }^{62}$ Although there were few instances of Orange attacks on Catholics outside Ulster before 1797, the terror of such an eventuality kept pace with signs of increasing reaction on the part of the authorities. By 1797 rumours that a yeomanry regiment was tinged with Orangeism were sufficient to enflame an area in which it was stationed, to swell the United Irish and Defender ranks with normally pacific peasants, and, as 1798 was to show only too clearly, to pre-empt the more sophisticated United Irish

\footnotetext{
${ }^{60}$ HO $100 / 64 / 168-72$.

61 Ibid.

62 For official anxieties that such measures might appear to sanction sectarian attacks, see correspondence between Portland and Camden, March-November 1796, HO $100 / 62 / 81,153-63,200-01$ and 337-39; also 100/63/142-55 and 177-80 for correspondence on the Insurrection Act in particular; The Speech of [ . . .] John Earl of Clare [. . .] in the House of Lords of Ireland [ . . ] on a motion made by the Earl of Moira, [ . . ] February 19, 1798 (Dublin, 1798); Senior, Orangeism in Ireland and Britain, pp. 51-80; Lecky, Ireland in the Eighteenth Century, III, pp. 37-39, 47-48 and 89-96.
} 
plans by sparking off a mindless jacquerie. ${ }^{63}$ Nor did the Orange impetus to treasonable organisation amongst the Catholics decline after the collapse of the United Irish movement, but continued to sustain Ribbonism until the middle of the nineteenth century. ${ }^{64}$

As soon as the sectarian bias of Defenderism became apparent, the temporary United Irish support for such an "alliance" began to crack under the strain of traditional religious divisions. Many Protestant United Irishmen were already suspicious of Defender motives. But even the Catholic leaders had never been totally happy about the connection, and after 1797 the more prosperous Catholics who dominated the Dublin leadership of the Society began to fear the consequences of the jacquerie into which they felt the "alliance" with the Defenders and the French Republic would transform their revolution. ${ }^{65}$ The United Irishmen were political but never social revolutionaries, and they baulked at the social aspects of the Defender programme. The nascent divisions within the Society were exacerbated by personal and cultural divisions, and ultimately were to have disastrous consequences for the projected rebellion and the fate of the United Irish movement.

But the militant Ulster leaders, who had originally sponsored the idea of an alliance with the Defenders, chafed at the restraints imposed on them by the moderate leaders of the South who dominated the executive. When the delayed rebellion finally did erupt in May 1798, the Northern sense of betrayal at the tardy and ill-co-ordinated efforts of their Southern comrades was as influential in the process of alienating the Ulster Protestants as their disgust at the religious character which the rebellion had assumed. ${ }^{66}$

63 Croker, Researches in the South of Ireland, op. cit., pp. 350-63; Powell, "The Background to the Wexford Rebellion", pp. 139-97; Kerrane, "The Background to the 1798 Rebellion", pp. 92-99; Lecky, Ireland in the Eighteenth century, III, pp. 97-100, 125-27, 131-33, 236-77. T. Pakenham, The Year of Liberty (London, 1969), gives a detailed account of this process before and during the Rebellion of 1798; also Carlow in '98, The Autobiography of William Farrell of Carlow, ed. by R. J. McHugh (Dublin, 1949), pp. 68, 74.

64 W. O'Hagan, Memoir on the Origins of [. . . Ribbonism (undated, c. 1838), Colonial Office Papers, Ireland, 904/7; see also National Library of Ireland, Ms. 13,842, for an example of a Caravet Oath, April 1799; State of the Country Papers 1403/17; Lewis, On Local Disturbances in Ireland, p. 168, note; Stewart, The Narrow Ground, p. 120.

65 For further information on the division, see M. Elliott, "The United Irishmen and France, 1792-1806" (D.Phil. thesis, Oxford University, 1975); see also Report from the Secret Committee of the Irish House of Lords (Dublin, 1798), p. 23, and various references in the Rebellion Papers 620/10/12/53, 18/14, 31/89, 36/226/7 and 37/45.

66 Evidence suggests that the divisions between the Protestant United Irishmen and the Catholics had already taken place before the Rebellion, though it was actually the more moderate Catholics who started the retreat: Andrew Newton to unknown, 9 February 
It was the latter, however, which alienated the rank-and-file Ulster Presbyterians from the United Irishmen and transformed what had been an almost exclusively Protestant movement in its formative years, into an equally exclusive Catholic one after 1798. By the following year Castlereagh was satisfied that Ulster had become a loyal province. Religious fears had pushed the Presbyterian United Irishmen into Orangeism and a corresponding influx of Catholics into the United movement was progressively diluting it with Defenderism.

the protestant dissenters in Ulster have in a great degree withdrawn themselves from the union, and become Orangemen. The Northern Catholics always committed in feeling against the Presbyterians, were during the early period of the Conspiracy loyal - the religious complexion of the Rebellions in the South gradually separated the Protestants from the Treason, and precisely in the same degree, appeared to embark the Catholics in it defenderism was introduced, and it is principally under that organization [...] that whatever there is of Treason in the North, is at present associated. ${ }^{67}$

The disappearance of Ulster as the spearhead of republicanism was swift and permanent. In conspiratorial movements of the early nineteenth century Ulster support is conspicuously absent, and although the economic reasons adduced by Gibbon to explain Ulster's support for the connection with England are valid, they are a later development. ${ }^{68}$

The significance of the events of the 1790's is not that they created widespread support for independence, but that they temporarily gave to existing discontent a republican leadership. The ideas of these leaders had been moulded by one and a half decades of campaigning against excessive English influence over Irish life, and latterly by the contagious ideas of the French Revolution. Theoretical republicanism only became active when faced with the deepening reaction of the British and Irish authorities after the outbreak of war in 1793. But its Protestant exponents had become so accustomed to political and social dominance that they failed to anticipate the different interpretation which the Catholic rank and file might impose on the new republicanism, and were shocked to discover that Catholic

1798, Rebellion Papers 620/35/130. For the later revulsion of the Ulster Protestants at the character of the Rebellion, and dismay at the attitudes of their Southern colleagues, see the correspondence between R. R. Madden and Dr McDonnel, 1843, Trinity College, Mss 873/378 and 381; Lord Annesley to unknown, 19 July 1804, State of the Country Papers 1030/30; Maria Duff to Mrs Clarke, 26 August 1798, Public Record Office Northern Ireland, D 1108/B/1-93.

67 Castlereagh to Portland, 3 June 1799, HO 100/87/5-7.

68 This is a recurrent theme in Gibbon, The Origins of Ulster Unionism, op. cit. 
republicanism was as much a weapon to oust the Protestant planters as to destroy English rule. The potent influence of intangibles in Irish history is frequently underestimated; it was by such intangibles, by the traditional hopes and fears latent in Irish society, that early Irish republicanism was transformed. The rising aspirations of the Defenders alienated many of the Protestant leaders, and mutual fears gave rise to atrocities which further embittered relations between the religious groupings. By the time of the 1798 rebellion, republican ideals seemed lost in what appeared to be an all-out war between the different religious sects. But if a secular republican movement seemed dead by the end of the century, the pattern for future republicanism had been firmly established. The Catholics had been invited to join the republican movement, but finished by taking it over. United Irish republicanism had not been entirely destroyed, rather a garbled version had been preserved for the future in the new martyrology and mythology of the 1790's, which the Catholics had made their own, and which provided much of the emotive passion behind subsequent movements. 